\title{
Sociodemographic characteristics and stress: The case of housekeeping and front office employees
}

\author{
Melita Josipović́ ${ }^{1}$, Jelena Tepavčević ${ }^{1 *}$, Viktorija Šimon ${ }^{1}$ \\ ${ }^{1}$ University of Novi Sad, Faculty of Science, Department of Geography, Tourism and Hotel \\ Management, Novi Sad, Serbia
}

\begin{abstract}
Stress at the workplace has an influence on job performance, employees' health, their job satisfaction and turnover intention. Due to frequent and intensive contact with customers, as well as characteristics of working in the hotel industry, stress can occur as a consequence. Therefore, the main aim of this study is to determine whether there is a difference in the perceived sources of stress among front office and housekeeping employees according to their sociodemographic characteristics (gender, age, education level and marital status). The research included 167 employees from the front office and housekeeping departments. The results show that sociodemographic characteristics of employees do not have an impact on their perceptions of sources of stress at the workplace. In addition, the impact of the working department on the perception is not significant. Due to the size of the sample, the generalization is not possible, but the results obtained in this study can be a guideline for the identification and reduction of the sources of stress in observed hotel departments.
\end{abstract}

Keywords: stress, housekeeping, front office, employees, sociodemographic characteristics JEL classification: L83, L89, Z30, Z39

\section{Sociodemografske karakteristike i stres: Slučaj zaposlenih u hotelskom domaćinstvu i na recepciji}

Sažetak: Stres na radnom mestu ima uticaja kako na radni učinak zaposlenih, njihovo zdravlje, zadovoljstvo poslom, tako i na namere napuštanja organizacije. Zbog čestog i intenzivnog kontakta sa korisnicima usluga, kao i zbog karakteristika rada u hotelijerstvu, stres se može pojaviti kao posledica. Na osnovu ovoga, glavni cilj ovog istraživanja je bio da se utvrdi da li postoji razlika u percepiranju izvora stresa među zaposlenima u domaćinstvu i na recepciji u zavisnosti od njihovih sociodemografskih karakteristika. Istraživanje je obuhvatilo 167 zaposlenih na recepciji i u domaćinstvu. Rezultati istraživanja su pokazali da sociodemografske karakteristike zaposlenih ne utiču na percepciju izvora stresa na radnom mestu. Pored toga, uticaj radnog sektora na percepciju izvora stresa nije značajan. Zbog veličine uzorka, generalizacija nije moguća, ali dobijeni rezultati mogu biti smernica za identifikaciju i smanjenje izvora stresa u posmatranim hotelskim odeljenjima.

Ključne reči: stres, domaćinstvo, recepcija, zaposleni, sociodemografske karakteristike JEL klasifikacija: L83, L89, Z30, Z39

* jelenat91@gmail.com 


\section{Introduction}

Stress can be considered as part of everyone's life and its importance in working life is growing. There is a range of stressors at work and in personal life to which individuals are exposed. Not every stressor affects all individuals the same. According to Erkutlu and Chafra (2006), workplace can be considered to be a potentially important source of stress because of the time spent in the workplace. The hospitality industry is widely acknowledged for the prevalence of stress (Kim et al., 2007; Papadopoulou-Bayliss et al., 2001; Wildes, 2007). Work in the hospitality industry is characterized by long working hours, lack of work control and conflicting work demands, which are, according to several authors, frequently cited as stressors (Bitner et al., 1994; Faulkner \& Patiar, 1997; Karatepe \& Uludag, 2007; Papadopoulou-Bayliss et al., 2001; Zohar, 1994). The hospitality industry gains benefits from continuous growth due to a growing number of travellers (Ernst \& Young, 2015). Considering the fact that hospitality industry is characterised by requirements for close cooperation between departments and personnel, time pressures, labour-intensive functions and intensive interpersonal relations (Birdir \& Tepeci, 2003; Kuruüzüm et al., 2008), the consequence can be the occurrence of workplace stress. Employees in customer-oriented fields often face conflicting demands of the company, supervisors and customers which creates dissonance for employees (Ruyter et al., 2001). On the other hand, organizations can gain benefits from happy employees, which can result in better job performances (Harter et al., 2003; Wright \& Cropanzano, 2000) and higher engagement at work (Huhtala \& Parzefall, 2007). The employees who are less stressed are likely to provide better service to customer compared to employees who are more stressed (Varca, 1999). As a result, the intense stress experienced by an employee can lead to a decision to leave an organization, which can cause a loss of well-trained personnel. This can result in a heavy cost for a hospitality organization (Lambert \& Hogan, 2009). In the accommodation industry, the high level of experienced stress can be a consequence of the lack of supportive environment for helping families, the lack of promotion opportunities as well as neglecting the ideas of the individual in the decision-making process (Karatepe \& Baddar, 2006).

The aim of the present study is to determine whether there are differences in the perceptions of sources of stress according to the sociodemographic characteristics of employees (gender, age, education level and marital status) and working department (housekeeping and front office).

\section{Theoretical background}

Since the hotel sector is a labour-intensive service industry, work stress is one of the most essential problems managers are facing. Ross (1995) found that it has an influence on the performance of all levels of employees, both hourly employees and managers. On the other hand, Gilboa et al. (2008) points to a higher level of negative correlation between stress and job performances among managers compared to non-managers. Also, exhaustion and cynicism can occur as a consequence of work stress in the hospitality industry (Kim, 2008), which can negatively affect the delivery of services. Siegrist and Theorell (2006) found that people who are overcommitted at work are more likely to experience stress and problems related to stress. According to Lo and Lamn (2005), poor working conditions and low wages are the main factors for causing stress in the hospitality industry. Besides this, the study conducted by O'Neill and Davis (2011) has found that the two most common stressors in the hotel industry are overloads and interpersonal tensions at work.

A lot of research has focused on the impact of gender on the perception of workplace stress (Almeida \& Kessler, 1998; O’Neill \& Davis, 2011). The results obtained in Almeida and 
Kessler's (1998) study indicate that women are generally more likely to experience daily stress than men. In addition to this, Michael et al. (2009) found that greater occupational stress is more prevalent among females compared to males. Furthermore, the authors found that age, educational level and marital status act as mediators in a relationship between gender and occupational stress. Sağbaş and Sürücü (2020) confirmed the results of previous research by finding women perceive stress more than men. In several studies, it was indicated that men experience higher level of stress than women (Cooper et al., 1989; Rossen et al., 1999). On the other hand, O`Neill and Davis (2011) have not found a significant impact of gender and marital status on the perception of stress. Besides gender, several authors pointed out that sociodemographic characteristics such as age (Rook et al., 1991), the level of education (Gallo \& Matthews, 2003) and marital status (Warr \& Parry, 1982) are related to stress. According to Jones and Brigght (2001), age can be considered as an individual differential factor that could be involved in the perception of work-related stress. In the study conducted by Acker (2004), it was found that the level of experienced stress among hotel employees vary depending on their age, that is, the older employees experience less stress than the younger ones. On the other hand, Sağbaş and Sürücü (2020) found no significant differences in the perception of job stress according to the age of employees. Considering the impact of educational level on the perception of stress, the negative relationship between educational level and experienced stress level was confirmed (Finkelstein et al., 2007; Gallo \& Matthews, 2003). There is a suggestion that people who are more educated are likely to deal better with the stressful situation than lower educated people (Finkelstein et al., 2007). Several studies pointed to the association of marital status with stress (Luecken et al., 1997; Throits, 2006). Research related to these issues have found that married employed women and women with children experience a higher level of stress than single women and men (Davidson \& Fielden, 1999; Luecken et al., 1997). The reason can be attributed to multiple roles which married women with children have to perform. Sağbaş and Sürücü (2020) confirmed the results of previous studies, that is, married women perceive higher level of stress than single women.

\section{Materials and methods}

\section{Measures}

For the purpose of this study, employees from hotel housekeeping and front office were selected. The questionnaire used in this research consisted of two parts. The first part of the questionnaire was related to the sociodemographic characteristics of employees (gender, age, education level, marital status and working department). The second part of the questionnaire contained the items related to the source of workplace stress. These items were completely adopted from Faulkner and Patiar's (1997) study which used a module for the source of stress from the Occupational Stress Indicator (OSI) developed by Cooper et al. (1988). In the original study, the 55 items which are considered to be the sources of stress were classified into six factors. The first factor, Factor Intrinsic to the Job consisted of eight items related to attitudes of employees towards their job (e.g. "Too much work", "Effects of minor tasks"). The second factor, The Role of Management (RM) is made up of nine items (e.g. "Implication of mistakes", "Ambiguity of job”, "Being visible/available”). The Relationship with Other People ("Personality clash", "Managing work of others", “Attending meetings") is the third factor and it consists of nine items referred to interpersonal relationships between employees who are working together. Within the fourth factor, Career and Achievement ("Chance of own development", "Change jobs, advance career", "Threat of redundancy") there are eight items which are related to the possibility of promotion which can be regarded as stressors. The fifth factor, Organization Structure and Climate (OSC) consisted of eleven 
items related to the problems with administration, lack of staff and it can be considered a quick picture of the association of organization and its employees (e.g. "Staff Shortages", "Organization Structure and Design", "Mundane Administration”). The last factor, Home and Work Interfere (HIW) consists of ten items referred to a negative process of interaction between home and work domains due to imbalance of roles (e.g. "Not been able to switch off", "Spouse attitude to my work", "Absence of emotional support"). For the evaluation of sources of stress was used 5-point Likert scale (1 - definitely not source of stress, 5 definitely a source of stress).

The research questions of this study are: 1) Are there significant differences in the perception of sources of stress according to the sociodemographic characteristics of employees such as gender, age, education and marital status? and 2) are there significant differences in the perception of sources of stress according to department in which they work?

\section{Data collection}

The data were collected during the spring and summer of 2019 in hotels in Serbia. The focus was on employees in two departments in a hotel: housekeeping and front office. The total of 170 employees was included in the research, but due to incomplete questionnaires, 3 were discarded from further analyses. The research was performed using a face-to-face survey.

\section{Results and discussion}

The first part of the questionnaire included information about the sociodemographic characteristics of employees. What can be noticed is a dominance of females in the sample (68.9\%, HK - 77\%, FO - 60\%) compared to males (31.1\%, HK - 23\%, FO - 40\%). In the housekeeping department, most of the employees are in the age group "36-45” (35.6\%), followed by age group "46-55” (32.2\%). On the other hand, among front office employees, the most are from age group "26-35” (52.5\%), followed by employees from age group "Up to 25 ” (23.8\%). Among housekeepers, $73.6 \%$ have completed only high school, while most of the front office employees have university degree (72.5\%). When it comes to marital status, most of the housekeeping employees are married (52.9\%), while in the front office department, employees are mainly in a relationship (38.8\%). Frequencies and percents for both departments are represented in Table 1.

Table 1: Sociodemographic characteristics of employees

\begin{tabular}{|c|c|c|c|c|}
\hline $\begin{array}{c}\text { Socio-demographic } \\
\text { characteristics }\end{array}$ & Frequency & Percent & Frequency & Percent \\
\hline & \multicolumn{2}{|c|}{ Housekeeping } & \multicolumn{2}{|c|}{ Front Office } \\
\hline \multicolumn{5}{|l|}{ Gender } \\
\hline Male & 20 & 23.0 & 32 & 40.0 \\
\hline Female & 67 & 77.0 & 48 & 60.0 \\
\hline \multicolumn{5}{|l|}{ Age } \\
\hline Up to 25 & 8 & 9.2 & 19 & 23.8 \\
\hline $26-35$ & 20 & 23.0 & 42 & 52.5 \\
\hline $36-45$ & 31 & 35.6 & 13 & 16.3 \\
\hline $46-55$ & 28 & 32.2 & 6 & 7.5 \\
\hline \multicolumn{5}{|l|}{ Education } \\
\hline High school & 64 & 73.6 & 15 & 18.8 \\
\hline Graduate & 22 & 25.3 & 58 & 72.5 \\
\hline Master & 1 & 1.1 & 7 & 8.8 \\
\hline \multicolumn{5}{|l|}{ Marital Status } \\
\hline Single & 10 & 11.5 & 24 & 30.0 \\
\hline
\end{tabular}




\begin{tabular}{|c|c|c|c|c|}
\hline In a relationship & 15 & 17.2 & 31 & 38.8 \\
\hline Married & 46 & 52.9 & 22 & 27.5 \\
\hline Divorced & 16 & 18.4 & 3 & 3.8 \\
\hline
\end{tabular}

Source: Author's research

Table 2 presents the results of a descriptive statistical (arithmetic mean and standard deviation of factors) and reliability analysis. The value of Cronbach ' $\alpha$ of all factors is higher than 0.7, which exceeds the recommended value (Kaiser, 1974) and indicates that all factors are in a domain of high reliability.

Employees in both departments agreed when it comes to the greatest source of stress, and that is The Management Role ( $\mathrm{HK}-4.000$, FO - 3.932). The situation is similar when it comes to the least source of stress - employees from both departments evaluated items within the factor Home and Work Interfere as the least sources of stress. In both cases, factor Factor Intrinsic to the Job has the smallest value of the standard deviation (HK - 0.59924, FO - 0.70917). There is a slightly larger deviation in the answers obtained from the front office employees. The same can be noticed for the factor Home and Work Interfere, which has the highest value of standard deviation in responses obtained from employees from both sectors (HK - 1.07410, FO - 1.09138).

Table 2: Results of descriptive statistical analysis

\begin{tabular}{|c|c|c|c|c|}
\hline \multirow{2}{*}{ FACTORS } & \multicolumn{2}{|c|}{ HOUSEKEEPING } & FRONT OFFICE \\
\cline { 2 - 5 } & Mean & $\begin{array}{c}\text { Std. } \\
\text { deviation }\end{array}$ & Mean & $\begin{array}{c}\text { Std. } \\
\text { deviation }\end{array}$ \\
\hline Factors intrinsic to the job $(\alpha=0.919)$ & 3.897 & 0.59924 & 3.713 & 0.70917 \\
\hline The management role $(\alpha=0.905)$ & $\mathbf{4 . 0 0 0}$ & 0.65581 & $\mathbf{3 . 9 3 2}$ & 0.72430 \\
\hline Relationship with other people $(\alpha=0.908)$ & 3.816 & 0.73582 & 3.599 & 0.89196 \\
\hline Career and achievement $(\alpha=0.907)$ & 3.727 & 0.95169 & 3.720 & 0.94074 \\
\hline Organization structure and climate $(\alpha=0.872)$ & 3.953 & 0.77906 & 3.919 & 0.86436 \\
\hline Home and work interfere $(\alpha=0.901)$ & $\mathbf{3 . 4 8 1}$ & 1.07410 & $\mathbf{3 . 3 5 5}$ & 1.09138 \\
\hline
\end{tabular}

Source: Author's research

Table 3 represents the results of t-test according to the gender of employees. For the purpose of obtaining more objective results and distinction of sources of stress among departments, the t-test according to gender was applied separately for both departments. In both cases, it has been found that there are no significant differences in responses obtained by housekeeping and front office employees according to their gender.

Table 3: T-test according to the gender of employees

\begin{tabular}{|c|c|c|c|c|c|c|c|c|}
\hline \multirow[b]{2}{*}{ Factors } & \multicolumn{2}{|c|}{ Housekeeping } & \multirow[b]{2}{*}{ t } & \multirow[b]{2}{*}{$\mathbf{p}$} & \multicolumn{2}{|c|}{ Front Office } & \multirow[b]{2}{*}{ t } & \multirow[b]{2}{*}{$\mathbf{p}$} \\
\hline & $\begin{array}{c}\text { Male } \\
(\mathrm{N}=20)\end{array}$ & $\begin{array}{l}\text { Female } \\
(\mathrm{N}=67)\end{array}$ & & & $\begin{array}{c}\text { Male } \\
(\mathrm{N}=32)\end{array}$ & $\begin{array}{l}\text { Female } \\
(\mathrm{N}=48)\end{array}$ & & \\
\hline FITJ & 3.844 & 3.912 & -0.447 & 0.656 & 3.813 & 3.646 & -0.447 & 0.656 \\
\hline MR & 4.028 & 3.992 & 0.215 & 0.831 & 3.969 & 3.907 & 0.215 & 0.831 \\
\hline ROP & 3.750 & 3.836 & -0.456 & 0.650 & 3.719 & 3.519 & -0.456 & 0.650 \\
\hline CA & 3.644 & 3.752 & 0.488 & 0.658 & 3.859 & 3.628 & -0.444 & 0.658 \\
\hline OSC & 3.775 & 4.006 & -1.166 & 0.247 & 4.006 & 3.860 & -1.166 & 0.247 \\
\hline HIW & 3.525 & 3.467 & 0.210 & 0.834 & 3.600 & 3.192 & 0.210 & 0.834 \\
\hline
\end{tabular}

Source: Author's research 
ANOVA test was performed separately for both observed departments. Six factors (Factors intrinsic to the job, The Management tole, Relationship with other people, Career and achievement, Organization structure and climate, Home and Work Interfere) were used as dependent variables, while sociodemographic characteristics of employees (age, education level and marital status) were used as an independent. Table 4 shows the results of the ANOVA test according to age among housekeeping and front office employees. It can be seen that there are no statistically significant differences in the perception of sources of stress according to their age. Due to this, the LSD post-hoc test was not performed.

Table 4: ANOVA according to age

\begin{tabular}{|c|c|c|c|c|c|c|c|}
\hline \multirow[b]{3}{*}{ Factors } & \multicolumn{4}{|c|}{ Housekeeping Department } & \multirow[b]{3}{*}{$\begin{array}{c}\mathrm{F} \\
\text { value }\end{array}$} & \multirow[b]{3}{*}{$\mathrm{t}$} & \multirow{3}{*}{$\begin{array}{l}\text { LSD } \\
\text { post- } \\
\text { hoc } \\
\text { test }\end{array}$} \\
\hline & \multicolumn{4}{|c|}{ Age } & & & \\
\hline & 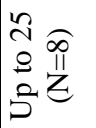 & 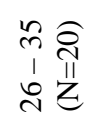 & 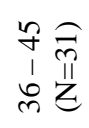 & 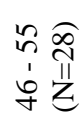 & & & \\
\hline FITJ & 3.469 & 3.856 & 3.936 & 4.005 & 1.783 & 0.157 & - \\
\hline MR & 3.958 & 3.900 & 3.986 & 4.099 & 0.376 & 0.771 & - \\
\hline ROP & 3.292 & 3.717 & 3.828 & 4.024 & 2.325 & 0.081 & - \\
\hline CA & 3.313 & 3.581 & 3.798 & 3.871 & 0.930 & 0.430 & - \\
\hline OSC & 3.538 & 3.795 & 4.026 & 4.104 & 1.497 & 0.221 & - \\
\hline \multirow[t]{2}{*}{ HWI } & 2.863 & 3.750 & 3.494 & 3.450 & 1.326 & 0.271 & - \\
\hline & \multicolumn{4}{|c|}{ Front Office Department } & & & \\
\hline FITJ & 3.567 & 3.667 & 4.019 & 3.833 & 1.208 & 0.313 & - \\
\hline MR & 3.743 & 3.881 & 4.154 & 4.407 & 1.826 & 0.150 & - \\
\hline ROP & 3.550 & 3.468 & 3.957 & 3.889 & 1.242 & 0.301 & - \\
\hline CA & 3.638 & 3.607 & 3.933 & 4.313 & 1.278 & 0.288 & - \\
\hline OSC & 3.795 & 3.871 & 4.185 & 4.067 & 0.632 & 0.597 & - \\
\hline HWI & 3.047 & 3.298 & 3.769 & 3.833 & 1.585 & 0.200 & - \\
\hline
\end{tabular}

Source: Author's research

Table 5 shows the results of ANOVA according to a level of education of employees. In the case of both observed departments, there are no statistically significant differences in the perception of sources of stress according to their education level. Thus, the LSD post hoc test was not performed.

Table 5: ANOVA according to education level

\begin{tabular}{|c|c|c|c|c|c|c|}
\hline \multirow[b]{3}{*}{ Factors } & \multirow{2}{*}{\multicolumn{3}{|c|}{$\begin{array}{c}\text { Housekeeping Department } \\
\text { Education } \\
\end{array}$}} & \multirow[b]{3}{*}{$\begin{array}{c}F \\
\text { value }\end{array}$} & \multirow[b]{3}{*}{$\mathbf{t}$} & \multirow[b]{3}{*}{$\begin{array}{c}\text { LSD } \\
\text { post-hoc } \\
\text { test }\end{array}$} \\
\hline & & & & & & \\
\hline & 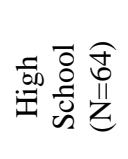 & 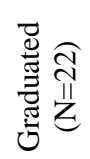 & 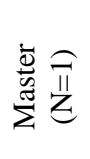 & & & \\
\hline FITJ & 3.914 & 3.875 & 3.250 & 0.618 & 0.541 & - \\
\hline MR & 3.977 & 4.081 & 3.667 & 0.329 & 0.721 & - \\
\hline ROP & 3.912 & 3.571 & 3.111 & 2.286 & 0.108 & - \\
\hline CA & 3.801 & 3.506 & 3.875 & 0.796 & 0.455 & - \\
\hline OSC & 4.041 & 3.696 & 4.000 & 1.632 & 0.202 & - \\
\hline \multirow[t]{2}{*}{ HWI } & 3.556 & 3.227 & 4.200 & 0.995 & 0.374 & - \\
\hline & \multicolumn{3}{|c|}{ Front Office Department } & & & \\
\hline FITJ & 3.833 & 3.662 & 3.875 & 0.544 & 0.582 & - \\
\hline MR & 4.111 & 3.879 & 3.984 & 0.624 & 0.538 & - \\
\hline
\end{tabular}


Josipović, M. et al. - Sociodemographic characteristics and stress: The case of housekeeping and front office employees - Hotel and Tourism Management, 2020, Vol. 8, No. 2: 53-63.

\begin{tabular}{|c|l|l|l|l|l|l|}
\hline ROP & 3.785 & 3.546 & 3.635 & 0.429 & 0.653 & - \\
\hline CA & 3.725 & 3.666 & 4.161 & 0.861 & 0.427 & - \\
\hline OSC & 4.207 & 3.829 & 4.043 & 1.222 & 0.300 & - \\
\hline HWI & 3.600 & 3.274 & 3.500 & 0.593 & 0.555 & - \\
\hline
\end{tabular}

Source: Author's research

Table 6 presents the results of variance ANOVA according to the marital status of employees. As can be noticed from the table, there are no statistically significant differences in perception of sources of stress among employees in both departments according to their marital status. Thus, the LSD post hoc test was not performed.

Table 6: ANOVA according to marital status

\begin{tabular}{|c|c|c|c|c|c|c|c|}
\hline \multirow[b]{3}{*}{ Factors } & \multirow{2}{*}{\multicolumn{4}{|c|}{$\begin{array}{c}\text { Housekeeping Department } \\
\text { Marital Status }\end{array}$}} & \multirow[b]{3}{*}{$\begin{array}{c}F \\
\text { value }\end{array}$} & \multirow[b]{3}{*}{ t } & \multirow[b]{3}{*}{$\begin{array}{l}\text { LSD } \\
\text { post } \\
\text { hoc }\end{array}$} \\
\hline & & & & & & & \\
\hline & 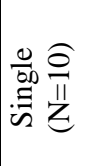 & 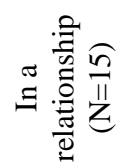 & 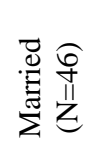 & 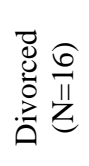 & & & \\
\hline FITJ & 3.900 & 3.883 & 3.807 & 4.164 & 1.428 & 0.240 & - \\
\hline MR & 4.033 & 4.044 & 3.978 & 4.000 & 0.047 & 0.986 & - \\
\hline ROP & 3.567 & 3.830 & 3.802 & 4.000 & 0.716 & 0.545 & - \\
\hline CA & 3.050 & 4.008 & 3.679 & 4.023 & 2.853 & 0.052 & - \\
\hline OSC & 3.480 & 4.020 & 4.007 & 4.031 & 1.412 & 0.245 & - \\
\hline \multirow[t]{2}{*}{ HWI } & 3.480 & 4.020 & 4.007 & 4.031 & 1.792 & 0.155 & - \\
\hline & \multicolumn{4}{|c|}{ Front Office Department } & & & \\
\hline FITJ & 3.546 & 3.690 & 3.903 & 3.875 & 1.032 & 0.383 & - \\
\hline MR & 3.699 & 3.857 & 4.279 & 4.037 & 2.813 & 0.055 & - \\
\hline ROP & 3.255 & 3.656 & 3.823 & 4.111 & 2.113 & 0.105 & - \\
\hline CA & 3.495 & 3.665 & 3.972 & 4.250 & 1.353 & 0.264 & - \\
\hline OSC & 3.613 & 3.994 & 4.082 & 4.400 & 1.696 & 0.175 & - \\
\hline HWI & 3.246 & 3.239 & 3.532 & 4.133 & 0.895 & 0.448 & - \\
\hline
\end{tabular}

Source: Author's research

\section{Conclusion}

Workplace stress has been widely examined for many years. Based on fact that work in hospitality industry is very stressful, it is necessary to examine and reduce sources of stress, because satisfied and empowered employees are the key in providing superb quality service (Malhotra \& Ackfeldt, 2016). Also, the hospitality employees are faced with uncertain situations (Jogaratnam \& Buchanan, 2004) which are increasing and together with an intensive relationship with customers, are an important source of stress in this industry. That is the reason why it is important to identify factors responsible for the occurrence of stress, which can result in benefits for the organization and employees. Also, the strategic use of the intervention tools for reducing stress is an important component of employee commitment to the organization. These tools can help managers to deal with the stress in a service-oriented work environment and produce a satisfied employee who will provide quality service to a customer.

The aim of the study was to determine if there are differences in the perception of sources of stress according to the sociodemographic characteristics of employees and working departments. Based on the results of the descriptive statistical analysis, the greatest source of stress for both departments is related to the role of management in the organization. It was 
noticed that organization structure and climate has very close values to management role, and this is especially expressed among front office employees, who almost equally valued management role (3.932) and organization structure and climate (3.919). The influence of managers on the well-being of employees can be negative, which can result in an increase of stress levels, cause depression (Sparks et al., 2001) and burnout (Huhtala \& Parzefall, 2007). Hence, managers need to be aware of the problems in the organization to find a solution as soon as possible. This can include creating a working environment which is minimally stressful for employees. Such a working environment can be created by implementing different strategies for managing workplace-related stress. Housekeeping employees, as well as front office employees, have the same perceptions regarding the least sources of stress at work. Employees in both departments agreed on the interference of home and work life and its small influence on work stress. This is contrary to the results obtained in the study by Rabenu et al. (2017) who found a strong association between job stress and work-family conflict. Based on the results of existing research (Almeida \& Kessler, 1998; Michael et al., 2009; Sağbaş \& Sürücü, 2020), it was assumed that females experience higher levels of stress than males. By applying t-test, it was tested whether there are statistically significant differences in the perception of sources of stress according to the gender of employees depending on the working department. It was found that the perception of sources of stress is not different among males and females employed both in housekeeping and front office departments. These results are in line with previous work (O`Neill \& Davis, 2011). In his study, Acker (2004) found that older employees experience less stress than younger. Based on this, it was assumed that the influence of age on the perception of sources of stress will be found. By applying the ANOVA analysis, it has been found that the perception of sources of stress does not differ depending on the age of employees in both departments. These results are in accordance with results obtained in Sağbaş and Sürücü's (2020) study. Starting from the suggestion that more educated employees deal better with a stressful situation (Finkelstein et al., 2007; Gallo \& Matthews, 2003), it was assumed that the results will show the influence of education level on the perception of sources of stress. The results of this study showed that there are no significant differences in the perception of sources of stress according to the education level of employees for both departments. The previous research in this field indicated the differences in the perception of stress among married and unmarried employees (Davidson \& Fielden, 1999; Luecken et al., 1997; Sağbaş \& Sürücü, 2020; Throits, 2006). Although previous research identified the impact of marital status on the perception of work stress, in this study was found no differences in perception of sources of stress among employees in both observed departments according to their marital status. The possible reason for these results can be an uneven representation of married/unmarried in the sample.

In order to respond to defined research questions, the study has revealed that the sociodemographic characteristics of employees (gender, age, level of education and marital status) do not influence the perceptions of sources of stress. In addition, the impact of the working department (housekeeping and front office) is not significant.

The nature of working in the hospitality industry is such that employees experience a higher level of stress than the average employee in other industries. The higher level of stress experienced by an employee can cause a drop in productivity, lower financial results, and can also affect the satisfaction of customers and their loyalty. The possible solution can be found in implementing stress-reducing techniques, which will have a positive influence on hospitality employees. Also, according to Arasli et al. (2017), good service climate can have a positive effect on employees ' perceptions and attitudes towards work and have moderating effects on consequences caused by stress. This means that a good working environment will help employees to deal with and fulfil their tasks and satisfy and delight the customers. 
The main limitation of this study can be the survey method used for collecting data. In the future research in-depth interview could be used for collecting in-depth data related to stress and sources of stress. Besides, the factors such as a number of children and their age were not included in this research. These factors can significantly affect the stress level of employees due to a conflict of roles. Hence, the recommendation for future research is to include these factors to obtain more precise results. Also, another recommendation for future research is to extend the current study on all departments in a hotel with the aim to identify main and potential sources of stress within different hotel departments. Also, the extension of this research should include the influence of stressors on job satisfaction and life satisfaction, as well as on burnout and turnover intentions.

\section{References}

1. Acker, G. M. (2004). The effect of organizational conditions (role conflict, role ambiquity, opportunities for professional development, and social support) on job satisfaction and intention to leave among social workers in mental health care. Community Mental Health Journal, 40(1), 65-73. https://doi.org/10.1023/B:COMH.0000015218.12111.26

2. Almeida, D. M., \& Kessler, R. C. (1998). Everyday stressors and gender differences in daily distress. Journal of Personality and Social Psychology, 75(3), 670-680. https://doi.org/10.1037/0022-3514.75.3.670

3. Arasli, H., Teimouri, R. B., Kiliç, H., \& Aghaei, I. (2017). Effects of service orientation on job embeddedness in hotel industry. Service Industry Journal, 37, 607-627. https://doi.org/10.1080/02642069.2017.1349756

4. Birdir, K., \& Tepeci, M. (2003). Otel genel müdürlerinde tükenmişlik sendromu ve tükenmişliğin genel müdür! erin işlerini değiştirme eğilimlerine etkileri [The burnout syndrome of hotel general managers and its effects on tendency of leaving job]. Anatolia: A Journal of Tourism Research, 14(2), 93-105.

5. Bitner, M. J., Booms, B. H., \& Mohr, L. A. (1994). Critical service encounters: The employee`s viewpoint. Journal of Marketing, 58, 95-106. https://doi.org/10.1177/002224299405800408

6. Cooper, C., Sloan, S., \& Williams, S. (1988). Occupational stress indicator management guide. Windsor: Nfer-Nelson.

7. Cooper, C. L., Rout, U., \& Faragher, B. (1989). Mental health, job satisfaction and job stress among general practitioners. British Medical Journal, 298(6670), 366-370. https://doi.org/10.1136/bmj.298.6670.366

8. Davidson, M. J, \& Fielden, S. (1999). Stress and the working woman. In G. N. Powell (Ed.), Handbook of gender and work (pp. 413-426). Thousand Oaks, CA: Sage.

9. Erkutlu, H. V., \& Chafra, J. (2006). Relationship between leadership power base and job stress of subordinates: Example from boutique hotels. Management Research News, 29, 285-297. https://doi.org/10.1108/01409170610674419

10. Ernst \& Young (2015). Global hospitality insights - Top thoughts for 2015. New York: EYGM Limited.

11. Faulkner, B., \& Patiar, A. (1997). Workplace induced stress among operational staff in the hotel industry. International Journal of Hospitality Management, 16, 99-117. https://doi.org/10.1016/S0278-4319(96)00053-9

12. Finkelstein, D. M., Kubzansky, L. D., Capitman, J., \& Goodman, E. (2007). Socioeconomic differences in adolescent stress: The role of psychological resources. Journal of Adolescent Health, 40(2), 127-134. https://doi.org/10.1016/j.jadohealth.2006.10.006 
13. Gallo, L. C., \& Matthews, K. A. (2003). Understanding the association between socioeconomic status and physical health: Do negative emotions play a role? Psychological Bulletin, 129(1), 10-51. https://doi.org/10.1037/0033-2909.129.1.10

14. Gilboa, S., Shirom, A., Fried, Y., \& Cooper, C. (2008). A meta-analysis of work demand stressors and job performance: Examining main and moderating effects. Personnel Psychology, 61(2), 227-272. https://doi.org/10.1111/j.1744-6570.2008.00113.x

15. Harter, J., Schmidt, F., \& Keyes, C. (2003). Wellbeing in the workplace and its relationship to business outcomes: A review of the gallup studies. In C. Keyes and J. Haidt (Eds.), Flourishing: The Positive Person and the Good Life (pp. 205-224). Washington, DC: American Psychological Association.

16. Huhtala, H., \& Parzefall, M. (2007), A review of employee wellbeing and innovativeness: An opportunity for a mutual benefit. Creativity and Innovation Management, 16(3), 299-306. https://doi.org/10.1111/j.1467-8691.2007.00442.x

17. Jogaratnam, G., \& Buchanan, P. (2004). Balancing the demands of school and work: Stress and employeed hospitality students. International Journal of Contemporary Hospitality Management, 16(4), 237-245. https://doi.org/10.1108/09596110410537397

18. Jones, F., \& Brigght, J. (2001). Stress: Myth, theory and research. Harlow, England: Prentice Hall.

19. Kaiser, H. F. (1974). An index of factorial simplicity. Psychometrika, 39(1), 31-36. https://doi.org/10.1007/BF02291575

20. Karatepe, O. M., \& Baddar, L. (2006). An empirical study of the selected consequences of frontline employees`work-family conflict and family-work conflict. Tourism Management, 28(1), 238-252. https://doi.org/10.1016/j.tourman.2005.10.024

21. Karatepe, O. M., \& Uludag, O. (2007). Conflict exhaustion, and motivation: A study of frontline employees in Northern Cyprus hotels. International Journal of Hospitality Management, 26, 645-665. https://doi.org/10.1016/j.ijhm.2006.05.006

22. Kim, H. J, Shin, K. H., \& Umbreit, W. T. (2007). Hotel job burnout: The role of personality characteristics. International Journal of Hospitality Management, 26, 421434. https://doi.org/10.1016/j.ijhm.2006.03.006

23. Kim, H. J. (2008). Hotel service providers`emotional labor: the antecedents and effects on burnout. International Journal of Hospitality Management, 27, 151-161. https://doi.org/10.1016/j.ijhm.2007.07.019

24. Kuruüzüm, A., Anafarta, N., \& Irmak, S. (2008). Predictors of burnout among middle managers in the Turkish hospitality industry. International Journal of Contemporary Hospitality Management, 20(2), 186-198.

25. Lambert, E., \& Hogan, N. (2009). The importance of job satisfaction and organizational commitment in shaping turnover intent: A test of causal model. Criminal Justice Review, 34(1), 96-118. https://doi.org/10.1177/0734016808324230

26. Lo, K., \& Lamn, F. (2005). Occupational stress in the hospitality industry - an employment relations perspective. New Zealand Journal of Employment Relations, 30, 22-48.

27. Luecken, L. J, Suarez, E. C., Kuhn, C. M., Barefoot, J. C., Blumenthal, J. A., Siegler, I. C., \& Williams, R. B. (1997). Stress in employed women: Impact of marital status and children at home on neurohormone output and home strain. Psychosomatic Medicine, 59(4), 352-359.

28. Malhotra, N., \& Ackfeldt, A. (2016). International communication and prosocial service behaviors of front-line employees: Investigating mediating mechanisms. Journal of Business Research, 69(10), 4132-4139. https://doi.org/10.1016/j.jbusres.2016.03.038

29. Michael, G., Anastasios, S., Helen, K., Catherine, K., \& Christine, K. (2009). Gender differences in experiencing occupational stress: The role of age, education, and marital status. Stress and Health, 25, 397-404. https://doi.org/10.1002/smi.1248 
30. O’Neill, J. W., \& Davis, K. (2011). Work stress and well-being in the hotel industry. International Journal of Hospitality Management, 30(2), 385-390. https://doi.org/10.1016/j.ijhm.2010.07.007

31. Papadopoulou-Bayliss, A., Ineson, E. M., \& Wilkie, D. (2001). Control and role conflict in food service providers. International Journal of Hospitality Management, 20, 187199. https://doi.org/10.1016/S0278-4319(00)00052-9

32. Rabenu, E., Tziner, A., \& Sharoni, G. (2017). The relationship between work-family conflict, stress, and work attitudes. International Journal of Manpower, 38(8), 11431156. https://doi.org/10.1108/IJM-01-2014-0014

33. Rook, K., Dooley, D., \& Catalano, R. (1991). Age differences in workers` efforts to come with economic distress. In J. Eckenrode (Ed.), The Social Context of Coping (pp. 79-105). New York: Plenum.

34. Ross, G. F. (1995). Work stress and personality measures among hospitality industry employees. International Journal of Contemporary Hospitality Management, 7(6), 9-14. https://doi.org/10.1108/09596119510095334

35. Rossen, L. N., Wright, K., Marlowe, D., Bartone, P., \& Gifford, R. K. (1999). Gender differences in subjective distress attributable to anticipation of combat among US soldiers deployed to the Persian Gulf during Operation Desert Storm. Military Medicine, 164, 753-757. https://doi.org/10.1093/milmed/164.11.753

36. Ruyter, K., Wetzels, M., \& Feinberg, R. (2001). Role stress in call centers: its effects on employee performance and satisfaction. Journal of Interactive Marketing, 15(2), 23-35. https://doi.org/10.1002/dir.1008

37. Sağbaş, M., \& Sürücü, L. (2020). Differences of perception of job stress according to the demographic characteristics of hotel employees. Journal of Tourism and Gastronomy Studies, 8(2), 805-815. https://doi.org/10.21325/jotags.2020.580

38. Siegrist, J., \& Theorell, T. (2006). Socioeconomic position and health: The role of work and employment. In J. Siegrist and M. Marmot (Eds.), Social Inequalities in Health: New Evidence and Policy Implications. Oxford University Press, Oxford. https://doi.org/10.1093/acprof:oso/9780198568162.003.0004

39. Sparks, K., Faragher, B., \& Cooper, C. (2001). Wellbeing and occupational health in the $21^{\text {st }}$ century workplace. Journal of Occupational and Organizational Psychology, 74(4), 489-509. https://doi.org/10.1348/096317901167497

40. Throits, P. A. (2006). Personal agency in the stress process. Journal of Health and Social Behaviour, 47, 309-323. https://doi.org/10.1177/002214650604700401

41. Varca, P. (1999). Work stress and customer service delivery. Journal of Services Marketing, 13(3), 229-241. https://doi.org/10.1108/08876049910273853

42. Warr, P. B., \& Parry, G. (1982). Paid employment and women`s psychological wellbeing. Psychological Bulletin, 91, 498-516. https://doi.org/10.1037/0033-2909.91.3.498

43. Wildes, V. J. (2007). Attracting and retaining food servers: How internal service quality moderates occupational stigma. Journal of Hospitality Management, 26, 4-19. https://doi.org/10.1016/j.ijhm.2005.08.003

44. Wright, T., \& Cropanzano, R. (2000). Psychological wellbeing and job satisfaction as predictors of job performance. Journal of Occupational Health Psychology, 5(1), 84-94. https://doi.org/10.1037/1076-8998.5.1.84

45. Zohar, D. (1994). Analysis of job stress profile in the hotel industry. International Journal of Hospitality Management, 13, 219-231. https://doi.org/10.1016/02784319(94)90022-1 